\title{
The Effect of Alloying on the Resistance of Carbon Steel for Oilfield Applications to $\mathrm{CO}_{2}$ Corrosion
}

\author{
David V. Edmonds*, Robert C. Cochrane \\ Institute for Materials Research, School of Process, Environmental and Materials Engineering, \\ University of Leeds, Leeds, LS2 9JT, United Kingdom
}

Received: July 19, 2004; Revised: October 21, 2005

\begin{abstract}
A systematic study has been conducted to investigate the influence of a wide range of alloying elements and different processing conditions on the resistance of low-carbon steels to $\mathrm{CO}_{2}$ corrosion. Strong carbide-forming microalloying elements such as $\mathrm{Ti}, \mathrm{Nb}$ and $\mathrm{V}$, along with $\mathrm{Cr}$ additions, and different levels of $\mathrm{Mn}, \mathrm{Si}, \mathrm{Cu}, \mathrm{Mo}$ and $\mathrm{Ni}$, have been explored, along with treatments simulating different processing conditions, for example, controlled rolling, and quenching and tempering. Corrosion testing, including flow loop tests, has been carried out, along with evaluation of mechanical properties, weldability and hot ductility. The programme has developed steels with improved $\mathrm{CO}_{2}$ corrosion resistance and hence identified a potential route for producing more economical carbon steels for oilfield applications. The work has been carried out as part of the UK- Brazil Corrosion Network.
\end{abstract}

Keywords: $\mathrm{CO}_{2}$ corrosion, carbon steels, microalloying

\section{Introduction}

The project was conceived under a UK-Brazil Corrosion Network focused upon the oil and gas industries. Arising from exchange visits and workshops in both the UK and Brazil, enabled by this network, three principal inter-related themes for research have been identified, which together could deliver innovative means of assuring the integrity of oilfield installations. The first of these themes is asset integrity management (AIM), which will extend plant life through life prediction and implementation of probabilistic inspection scheduling. The second theme, to which this paper relates, is promoting relevant studies of the corrosion mechanisms in production conditions and hence should also develop realistic models to foresee its occurrence. The third area of focus is in developing radical means of corrosion control and engineered surfaces to enable inherently corrosion resistant carbon and low-alloy linepipe steels, together with remedial measures, to minimise the impact on the environment. The justification, and economic and environmental benefits for the direction of this overall programme, stem from the fact that $10 \%$ of the cost of lifting a barrel of oil can be attributed to the cost of wellhead and pipeline corrosion, and $95 \%$ of the constructional materials used in the oil and gas industries is, and will be for the foreseeable future, carbon steel. The overall objective of the network research programmes is to achieve a reduction in capital expenditure (CAPEX) costs of around $8 \%$ and a corresponding reduction in operating costs (OPEX) of close to $10 \%$.

The more common forms of corrosion encountered in transmission gas/oil pipelines and in well-head applications ('down-hole') are associated with the presence of $\mathrm{H}_{2} \mathrm{~S}$ or $\mathrm{CO}_{2}$. Although $\mathrm{CO}_{2}$ in aqueous solution forms a weak acid, its ability to produce a significant, deep, localized or uniform attack is considerable ${ }^{2}$. The problem with $\mathrm{CO}_{2}$ corrosion is that a wide variation in corrosion behaviour is frequently observed even for steels of nominally the same grade or similar steels manufactured by different processing routes. A particular issue is the localised form of corrosion known as mesa attack in which some local event initiates very rapid corrosion leading to premature failure ${ }^{3,4}$. Current strategies for dealing with this form of severe corrosion are deliberately conservative and often result in the use of highly alloyed expensive duplex stainless steels in order to avoid premature failure particularly in 'down-hole' applications. An alternative strategy is to use corrosion inhibitors and corrosion monitoring to prolong the life of a more conventional low cost carbon steel. Even where carbon steels have been used in such applications high failure rates are not uncommon, about $60 \%$ of oilfield failures result from $\mathrm{CO}_{2}$ corrosion, primarily due to inadequate knowledge or predictive capability, and the poor resistance of carbon and low alloy steels to this form of attack ${ }^{5-7}$. The same form of corrosion can also occur in gas or oil transmission pipelines where, for purely economic and weldability reasons, a carbon steel must be used and, despite efforts to predict installation lifetimes using models of the corrosion process, premature leaks are not uncommon. Consequently, more reliable corrosion performance of plain carbon pipeline steels in this medium is urgently required.

A particular aspect of steel development receiving much attention recently is the role of 'passive films' in limiting corrosion or propensity to mesa attack $^{8,9} ; \mathrm{Cr}$ additions have an important role in this regard ${ }^{10-15}$. In addition, the compositions, microstructures and processing histories of modern constructional steels bear little resemblance to those in use as little as a decade or so ago. Consequently, the work reported in this paper may be perceived to stem from these radical developments in steelmaking technology and the application of microalloying and controlled processing that have taken place in recent times in carbon steel metallurgy. New methods have been utilised for maintaining or improving strength and toughness levels by alloying, frequently coupled with controlled processing. However, the effects of these alloying additions, or the processing conditions employed and the microstructures developed, on corrosion resistance, are not understood. In consequence, this work seeks to understand better how some of these new factors influence corrosion whilst also attempting to exploit the opportunities presented for enhanced corrosion performance. Essentially a development programme ${ }^{16,17}$, it nonetheless raises some new issues concerning corrosion mechanisms and corrosion performance. 
The experimental programme was sponsored and steered by an industry partnership of four oil companies, Agip (Italy), BP (UK), Elf (France) and Statoil (Norway); and three steelmakers, Corus Group (UK-Netherlands), Dalmine (Tenaris Group) (Italy) and Vallourec (France), and the work was carried out at the University of Leeds (UK) in association with the Institute of Energy Technology (IFE), Norway. This partnership group established a target and approach at the beginning of the programme.

\subsection{The target}

- $\mathrm{CO}_{2}$ corrosion resistance 3-4 times higher than the currently used grades of linepipe carbon steel;

- A price increase of no more than $1 \frac{1}{2}$ times the alloying cost of the currently used carbon steel grades; and

- Adequate mechanical properties and indicative weldability based upon bead-on-plate hardness test data.

\subsection{The approach}

- Increase $\mathrm{CO}_{2}$ corrosion resistance of a microalloyed carbon steel by alloying, principally with $\mathrm{Cr}$, but also explore the same with minor additions of other elements e.g. Si, $\mathrm{Mo}, \mathrm{Cu}$;

- Restrict the carbon concentration: target range 0.02-0.05 wt. (\%), thereby reducing the tendency for chromium carbide formation and also as a means of counteracting the effect of $\mathrm{Cr}$ on weld heat affected zone hardness; and

- Introduce strong carbide-forming microalloying elements and maintain concentrations at $50 \%$ above the respective alloy carbide stoichiometric ratios with carbon, both to protect the $\mathrm{Cr}$ in solid solution and also to achieve the mechanical properties desired: strength and toughness requirements through grain size refinement, and also from the formation of acicular bainitic structures, and precipitation strengthening from alloy carbides.

In addition it was thought desirable to:

- Restrict alloying to $5 \mathrm{wt}$. (\%) maximum to minimise any segregation problems; and

- Adjust C, S, P and O levels to that equivalent to an HIC-resistant steel: $0.02-0.05 \mathrm{C} ;<0.002 \mathrm{~S} ;<0.015 \mathrm{P} ;<0.002 \mathrm{O}$.

The above resulted in an initial alloy base of: $0.04, \mathrm{C} 0.5 \mathrm{Mn}$, $0.3 \mathrm{Si}$, plus combinations of $\mathrm{Cr}, \mathrm{Mo}, \mathrm{Cu}, \mathrm{Nb}, \mathrm{V}$, Ti.

\section{Experimental Procedures}

Design of the compositions of the experimental steels was according to the following intentions: Base steel: Carbon 0.03-0.07; Manganese $0.5-1.0$, but mainly held at 0.5 ; Silicon $0.3-1.0$, but mainly enhanced to 0.6; Chromium 0, 0.5, 1.0, 1.5, 2.0, 3.0, 5.0; Microalloying: based upon single or combination additions of Niobium 0.03-0.06, Titanium 0.03-0.36, Vanadium 0.14-0.36; and Others: Molybenum 0.3-0.5, Copper 0.25, Nickel 0.2-0.5. The compositions achieved are given in Table 1.

The steels were prepared and treated in various ways: at first, $50 \mathrm{~g}$ argon arc and $800 \mathrm{~g}$ induction melts, mainly for sorting, followed by a more limited number of $60 \mathrm{~kg}$ vacuum induction melts of promising compositions for simulating manufacturing routes for different oilfield applications, and for final corrosion assessment:

(i) For pipelines (BOS/con-cast - TMCR/AC plate - formed and welded): Experimental Treatments: Increasing levels of simulation - Controlled cooling in a high-speed dilatometer; Gleeble experiments to introduce single-step deformation; Pilot plant scale controlled-rolling at Corus Group Technology Centre. This latter group were the most representative of commercially sized casts, and were examined in the as-received hot-rolled condition (AR) and in the controlledrolled state (CR). The $150 \mathrm{~mm}$ square $60 \mathrm{~kg}$ ingots were cut into two, soaked for 1 hour at $1250{ }^{\circ} \mathrm{C}$, and then half was rolled to $15 \mathrm{~mm}$ plate in 10 passes with an $1150{ }^{\circ} \mathrm{C}$ roll start temperature, to give the samples designated $\mathrm{AR}$, and the other half rolled to $90 \mathrm{~mm}$ thickness with an $1150{ }^{\circ} \mathrm{C}$ roll start temperature, and then held to $900{ }^{\circ} \mathrm{C}$ before rolling to $15 \mathrm{~mm}$ thickness with a final rolling temperature of $850^{\circ} \mathrm{C}$, to give the samples designated CR; and

(ii) For downhole tubing (BOS or Electric Arc/con-cast - pierced and seamless rolled tube - quenched and tempered): Experimental Treatments: Samples in the as-rolled (AR) condition, i.e. soaked for 1 hour at $1250{ }^{\circ} \mathrm{C}$, and then rolled to $15 \mathrm{~mm}$ plate in 10 passes with an $1150{ }^{\circ} \mathrm{C}$ roll start temperature, were re-austenitised for 45 minutes at $910{ }^{\circ} \mathrm{C}$, water quenched into agitated brine and tempered for 1 hour at $625^{\circ} \mathrm{C}$ (treatment QT).

The corrosion testing programme began with a large number of simple sorting tests, mainly of samples from the small-scale melts, followed by more limited flow loop testing at the Institute of Energy Technology, IFE, Norway, of the more promising steel compositions identified of samples processed in different ways from the $60 \mathrm{~kg}$ melts. Oxidised samples were also subjected to corrosion testing, in an attempt to simulate the effect on corrosion of mill scale. The oxidation was carried out in air at $550{ }^{\circ} \mathrm{C}$ for 1 week.

(i) Sorting corrosion tests: Full polarisation curve and linear polarisation resistance tests were made of the full range of experimental steels. The use of a high $\mathrm{pH}$ for full polarisation testing indicated the ability of the steels to passivate in the locally alkalinised conditions prevailing beneath corrosion films. Cylindrical dilatometer samples with a surface area of approximately $2 \mathrm{~cm}^{2}$ were used. Examples of the type of 1-litre corrosion cell apparatus used, designed according to ASTM Standard G5-87, are illustrated in Figure 1. Twin platinum counter-electrodes were used, place equi-distant from the sample and separated from the corrosion medium by fritted glass discs. A saturated calomel reference electrode was used, positioned close to the specimen surface using a luggin probe and vycor frit. A pH electrode located in the cell allowed constant monitoring of the solution $\mathrm{pH}$ throughout the test. $\mathrm{CO}_{2}$ was bubbled through the solution for 1 hour prior to testing; exiting the cell via a water lock, and vigorous stirring of the solution was employed throughout both conditioning and testing. Corrosion rate in $\mathrm{mm} / \mathrm{year}$ was calculated from the full polarisation and linear polarisation resistance tests and steels could also be correspondingly ranked according to critical current density. Conditions: Full polarisation tests in $1 \% \mathrm{NaCl}+$ $\mathrm{NaHCO}_{3}-\mathrm{pH} 8.4\left(20^{\circ} \mathrm{C}\right.$, 0.6 $\left.\mathrm{Bar} \mathrm{CO}_{2}\right)$; Linear polarisation tests in Forties brine - pH 5.4: $\left(20^{\circ} \mathrm{C}, 1.0 \mathrm{Bar}^{\mathrm{CO}_{2}}\right)$; and

(ii) Flow loop corrosion tests: The flow loop apparatus is illustrated in Figure 2 and can be used at a maximum pressure of $25 \mathrm{Bar}$ over a temperature range from $5{ }^{\circ} \mathrm{C}$ to $100{ }^{\circ} \mathrm{C}$. Flat specimens $25 \times 25 \times 3 \mathrm{~mm}$, lacquered on all but one test surface, were used in both test racks, separated by PTFE spacers to prevent galvanic coupling, and with flow straighteners upstream and downstream. The test circuit was opened when $\mathrm{pH}$, temperature and pressure were stable. Mass loss measurements and linear polarisation resistance were used to determine the corrosion rate. Conditions: $1 \% \mathrm{NaCl}+\mathrm{NaHCO}_{3}-\mathrm{pH} 4.5$ (gas regime, no $\mathrm{FeCO}_{3}$ scale); Forties brine - pH 5.6 (oil regime, $\mathrm{FeCO}_{3}$ scale formed): $\left(50{ }^{\circ} \mathrm{C}, 1.0 \mathrm{Bar}^{\mathrm{CO}_{2}},(\mathrm{Fe})<50 \mathrm{ppm}, 14\right.$ days test run). Pre-oxidised specimens were also tested (the oxide layer was $10-20 \mu \mathrm{m}$ thick after 1 week at $550{ }^{\circ} \mathrm{C}$ ). 
Table 1. Compositions of reference steel X70 and experimental steels (in wt. (\%)) (Ceq is the carbon equivalent value).

\begin{tabular}{|c|c|c|c|c|c|c|c|c|c|c|c|c|c|c|}
\hline Steel & $\mathrm{C}$ & $\mathrm{Mn}$ & $\mathrm{Si}$ & $\mathrm{Cr}$ & $\mathrm{Nb}$ & $\mathrm{Ti}$ & Mo & $\mathrm{V}$ & $\mathrm{Cu}$ & $\mathrm{Ni}$ & $\mathrm{Al}$ & $\mathrm{N}$ & $\begin{array}{l}\text { Price } \\
\text { Factor }\end{array}$ & Ceq \\
\hline X70 & 0.050 & 1.60 & 0.27 & 0.02 & 0.06 & 0.004 & 0.00 & 0.002 & 0.02 & 0.0 & 0.000 & - & 1.00 & 0.32 \\
\hline A1 & 0.040 & 0.50 & 0.30 & 1.00 & 0.03 & 0.000 & 0.00 & 0.000 & 0.00 & 0.0 & 0.000 & - & 1.01 & 0.32 \\
\hline B1 & 0.040 & 0.50 & 0.60 & 0.50 & 0.03 & 0.000 & 0.30 & 0.000 & 0.00 & 0.0 & 0.000 & - & 1.08 & 0.28 \\
\hline $\mathrm{C} 1$ & 0.040 & 0.50 & 0.30 & 1.00 & 0.03 & 0.000 & 0.30 & 0.000 & 0.00 & 0.0 & 0.000 & - & 1.10 & 0.38 \\
\hline D1 & 0.040 & 0.50 & 0.60 & 1.00 & 0.03 & 0.000 & 0.30 & 0.000 & 0.00 & 0.0 & 0.000 & - & 1.13 & 0.38 \\
\hline E1 & 0.040 & 0.50 & 0.30 & 1.50 & 0.03 & 0.000 & 0.30 & 0.000 & 0.00 & 0.0 & 0.000 & - & 1.16 & 0.48 \\
\hline F1 & 0.040 & 0.50 & 0.30 & 1.00 & 0.00 & 0.030 & 0.00 & 0.000 & 0.00 & 0.0 & 0.000 & - & 1.00 & 0.32 \\
\hline F1A & 0.040 & 1.50 & 0.30 & 1.00 & 0.00 & 0.030 & 0.00 & 0.000 & 0.00 & 0.0 & 0.000 & - & 1.07 & 0.49 \\
\hline F1B & 0.040 & 0.50 & 0.30 & 1.00 & 0.00 & 0.060 & 0.00 & 0.140 & 0.00 & 0.0 & 0.000 & - & 1.10 & 0.35 \\
\hline $\mathrm{F} 2$ & 0.061 & 0.50 & 0.60 & 1.50 & 0.00 & 0.360 & 0.30 & 0.000 & 0.25 & 0.0 & 0.000 & - & 1.26 & 0.52 \\
\hline F3 & 0.060 & 0.50 & 0.60 & 3.00 & 0.00 & 0.360 & 0.30 & 0.000 & 0.25 & 0.0 & 0.000 & - & 1.41 & 0.82 \\
\hline G1 & 0.040 & 0.50 & 0.60 & 1.50 & 0.00 & 0.030 & 0.30 & 0.000 & 0.00 & 0.0 & 0.000 & - & 1.17 & 0.48 \\
\hline H1 & 0.030 & 0.50 & 0.30 & 1.50 & 0.06 & 0.060 & 0.30 & 0.000 & 0.00 & 0.0 & 0.000 & - & 1.19 & 0.47 \\
\hline H1A & 0.030 & 0.50 & 0.30 & 1.50 & 0.06 & 0.060 & 0.00 & 0.000 & 0.00 & 0.0 & 0.000 & - & 1.09 & 0.41 \\
\hline I1 & 0.030 & 0.50 & 0.30 & 2.00 & 0.06 & 0.060 & 0.30 & 0.000 & 0.00 & 0.0 & 0.000 & - & 1.24 & 0.57 \\
\hline J1 & 0.040 & 0.50 & 0.30 & 1.50 & 0.00 & 0.000 & 0.00 & 0.250 & 0.00 & 0.0 & 0.000 & - & 1.21 & 0.47 \\
\hline J1A & 0.040 & 0.50 & 0.30 & 1.50 & 0.00 & 0.000 & 0.30 & 0.250 & 0.00 & 0.0 & 0.000 & - & 1.30 & 0.53 \\
\hline J1B & 0.040 & 0.50 & 0.30 & 1.50 & 0.00 & 0.000 & 0.30 & 0.250 & 0.30 & 0.0 & 0.000 & - & 1.32 & 0.55 \\
\hline $\mathrm{J} 2$ & 0.067 & 0.54 & 0.60 & 1.49 & 0.00 & 0.000 & 0.31 & 0.360 & 0.26 & 0.0 & 0.033 & - & 1.42 & 0.61 \\
\hline $\mathrm{J} 3$ & 0.067 & 0.54 & 0.60 & 2.95 & 0.00 & 0.000 & 0.31 & 0.360 & 0.26 & 0.0 & 0.041 & - & 1.58 & 0.90 \\
\hline K1A & 0.040 & 0.50 & 0.30 & 3.00 & 0.00 & 0.200 & 0.50 & 0.000 & 0.30 & 0.2 & 0.000 & - & 1.46 & 0.86 \\
\hline L1 & 0.040 & 0.50 & 1.00 & 3.00 & 0.00 & 0.200 & 0.50 & 0.000 & 1.00 & 0.5 & 0.000 & - & 1.63 & 0.92 \\
\hline M1 & 0.040 & 0.50 & 1.00 & 3.00 & 0.00 & 0.000 & 0.00 & 0.000 & 0.00 & 0.0 & 0.000 & - & 1.26 & 0.72 \\
\hline M1A & 0.040 & 0.50 & 0.30 & 3.00 & 0.00 & 0.000 & 0.00 & 0.000 & 0.00 & 0.0 & 0.000 & - & 1.20 & 0.72 \\
\hline N1 & 0.040 & 0.50 & 1.00 & 5.00 & 0.00 & 0.000 & 0.00 & 0.000 & 0.00 & 0.0 & 0.000 & - & 1.47 & 1.12 \\
\hline N1A & 0.040 & 0.50 & 0.30 & 5.00 & 0.00 & 0.000 & 0.00 & 0.000 & 0.00 & 0.0 & 0.000 & - & 1.41 & 1.12 \\
\hline $\mathrm{J} 2-60 \mathrm{~kg}$ & 0.066 & 0.54 & 0.61 & 1.48 & 0.00 & 0.000 & 0.31 & 0.360 & 0.26 & 0.0 & 0.040 & 0.0061 & 1.42 & 0.60 \\
\hline $\mathrm{J} 3-60 \mathrm{~kg}$ & 0.066 & 0.53 & 0.62 & 2.95 & 0.00 & 0.000 & 0.31 & 0.360 & 0.26 & 0.0 & 0.040 & 0.0088 & 1.58 & 0.90 \\
\hline $\mathrm{H} 2-60 \mathrm{~kg}$ & 0.039 & 0.53 & 0.61 & 1.49 & 0.08 & 0.030 & 0.31 & 0.050 & 0.26 & 0.0 & 0.040 & 0.0068 & 1.27 & 0.51 \\
\hline $\mathrm{F} 3 \mathrm{a}-60 \mathrm{~kg}$ & 0.034 & 0.51 & 0.62 & 2.89 & 0.00 & 0.170 & 0.30 & 0.000 & 0.26 & 0.0 & 0.030 & 0.0075 & 1.37 & 0.77 \\
\hline $\mathrm{F} 3 \mathrm{~b}-60 \mathrm{~kg}$ & 0.067 & 0.51 & 0.61 & 2.88 & 0.00 & 0.380 & 0.30 & 0.000 & 0.26 & 0.0 & 0.020 & 0.0094 & 1.41 & 0.81 \\
\hline $\mathrm{J} 4 \mathrm{a}-60 \mathrm{~kg}$ & 0.037 & 0.53 & 0.59 & 2.93 & 0.00 & 0.000 & 0.00 & 0.120 & 0.26 & 0.0 & 0.030 & 0.0089 & 1.32 & 0.75 \\
\hline $\mathrm{J} 4 \mathrm{~b}-60 \mathrm{~kg}$ & 0.031 & 0.53 & 0.60 & 2.93 & 0.00 & 0.000 & 0.30 & 0.120 & 0.26 & 0.0 & 0.030 & 0.0090 & 1.41 & 0.81 \\
\hline
\end{tabular}

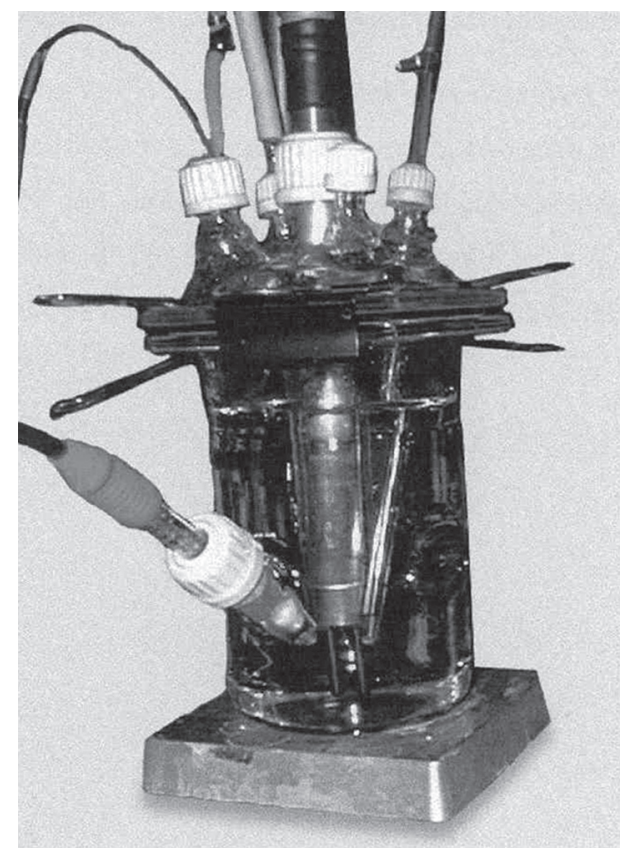

Figure 1. Two of the types of corrosion cell used.

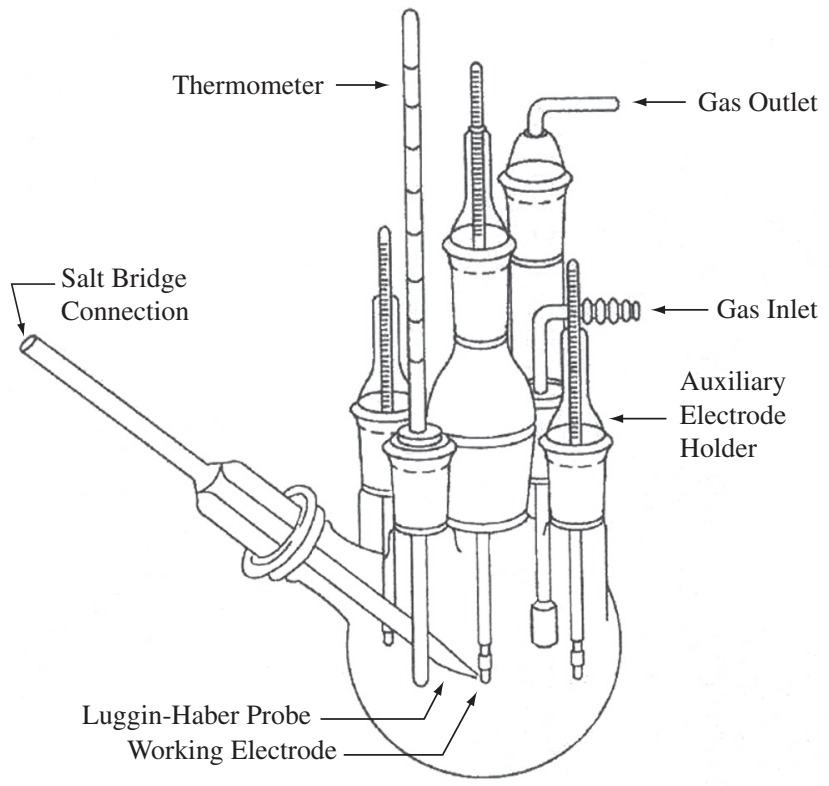




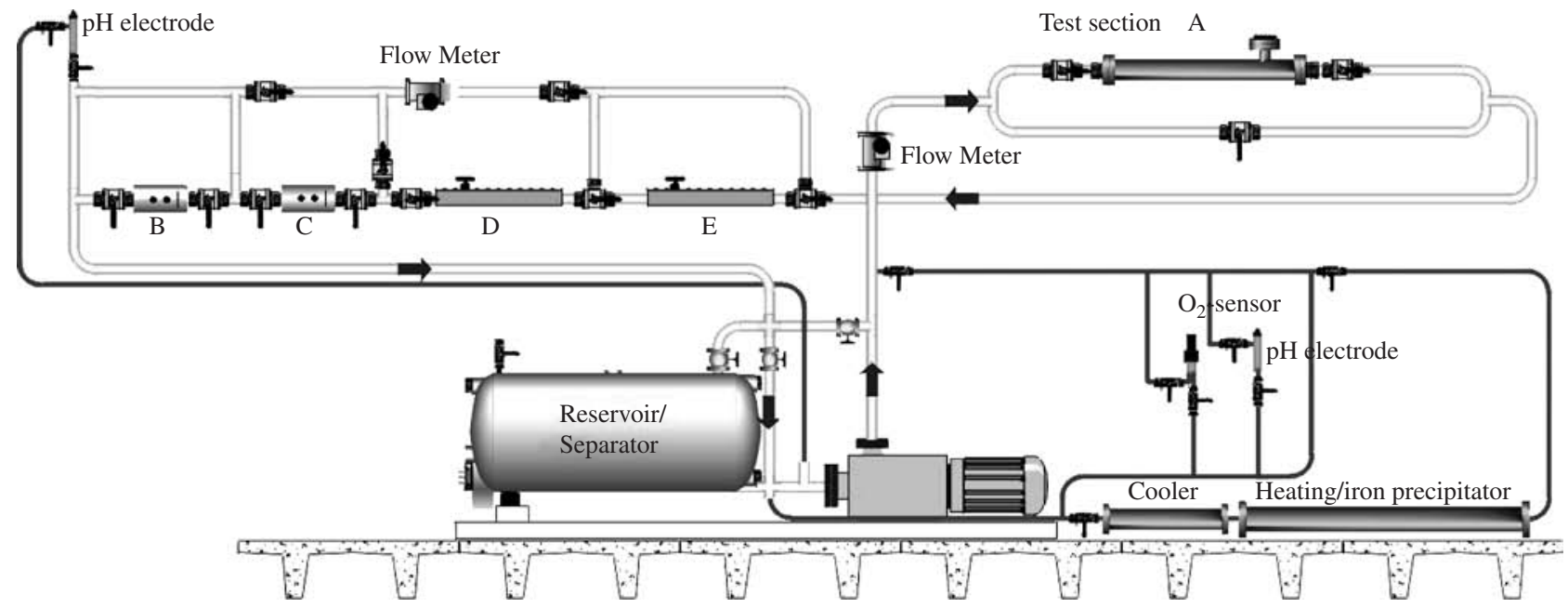

Figure 2. Diagram of flow loop apparatus (Courtesy of IFE, Norway).

Metallographic examination of steel microstructures and corrosion layers was conducted by light microscopy and scanning electron microscopy. Samples were prepared by conventional methods of sectioning followed by grinding, mechanical polishing and etching.

Mechanical properties were assessed using standard procedures. Hardness was measured using a Vickers pyramidal diamond indenter under a $10 \mathrm{~kg}$ load. Tensile properties - Proof/Ultimate strengths, elongation - were measured at room temperature using an Instron 1185 testing machine. Charpy impact toughness was measured over the temperature range $-90^{\circ} \mathrm{C}$ to $50{ }^{\circ} \mathrm{C}$ using standard $10 \mathrm{~mm}$ Charpy V-notch specimens.

Hot ductility tests were carried out to assess resistance to transverse slab cracking during continuous casting. The tests were conducted according to a method devised by Mintz ${ }^{18}$ and illustrated in Figure 3. Cylindrical specimens $7.9 \mathrm{~mm}$ diameter by $110 \mathrm{~mm}$ length, with threaded ends and an inserted central thermocouple, are encased in a silica tube under an inert atmosphere in an induction furnace. The centre of the sample is then melted at $1540{ }^{\circ} \mathrm{C}$ before cooling to temperatures in the range $700-1100{ }^{\circ} \mathrm{C}$, holding at temperature for 5 minutes, and then tensile testing to failure at a strain rate of $3 \times 10^{-3} \mathrm{~s}^{-1}$.

Standard bead-on-plate weldability tests were made according to BS7363:1990. Conditions: Arc voltage $10 \pm 0.5 \mathrm{~V}$ Electrode DC Negative; Current $200 \pm 5$ A; Travel Speed $120 \pm 5 \mathrm{~mm} / \mathrm{min}$; Nominal Arc Energy $1.0 \mathrm{~kJ} / \mathrm{mm}$.

Thermodynamic phase diagram calculations, using MTDATA and ThermoCalc, allowed construction of segments of the equilibrium phase diagrams of the experimental steels, to assist with interpretation of the effects of the alloying element additions upon microstructure during heat treatment and processing. An MTDATA package ${ }^{19}$ and SGTE (Scientific Group Thermodata Europe) solution database ${ }^{20}$ were used.

\section{Results and Discussion}

Results of the initial bench-top corrosion testing programme are shown in Figure 4, and demonstrate that the alloying approach could improve the corrosion resistance above that of X70 steel. Chromium addition was most effective, as expected, but so were some of the other element additions considered. Differences could also be identified between the different conditions of the steels: in the hot-rolled condition (AR), in the controlled-rolled state (CR) or quenched and

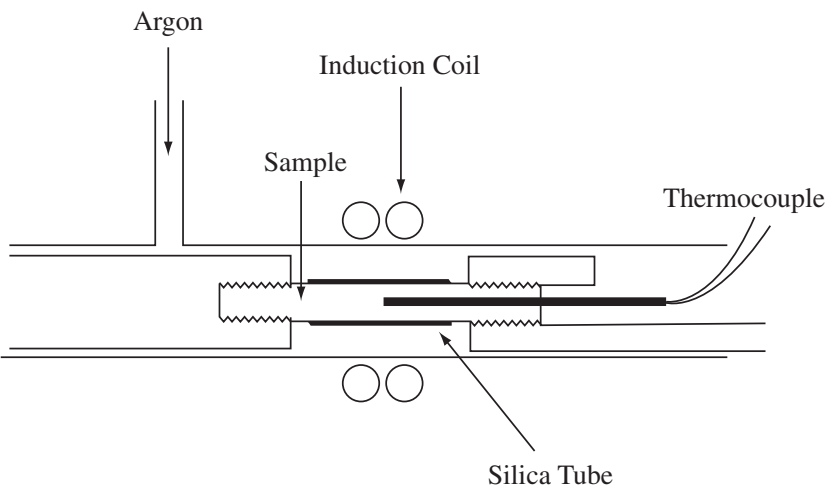

Figure 3. Schematic diagram of the apparatus used for hot ductility testing. (Courtesy of B. Mintz, City University, UK).

tempered (QT). Following the promise of these preliminary tests a schedule of flow loop tests, more representative of oil-field conditions, was conducted on the steels showing most potential, and the results are given in Figure 5. Again the alloyed steels exhibited more resistance to corrosion than X70 steel, and moreover, the best steels had a corrosion rate 5 times better than that of X70, meeting the initial target set. The tests also showed the initial corrosion rate of the experimental steels decreasing with time, whereas that of the X70 steel increased with time (Figure 6). This suggests the development of a protective surface film passivating the corrosion reaction, and evidence of this was observed. Figure 7 shows the cross-section of the corrosion film on a 3\% Cr steel (J4a) flow-loop tested for 14 days in Forties brine. This film was adherent, with uniform thickness $(\sim 50-100 \mu \mathrm{m})$, and few cracks (despite drying at $70{ }^{\circ} \mathrm{C}$ before observation by scanning electron microscopy). Energy dispersive X-ray analysis indicated that the film was $\mathrm{Cr}$-rich, and also contained $\mathrm{V}$ that was an addition to this steel $(0.12$ wt. $(\%))$.

Metallographic examination of the microstructures of the experimental steels indicated that those of the hot-rolled and controlledrolled samples were predominantly ferritic (Figure 8), although not the regular equiaxed ferrite normally recognisable in plain carbon steels, but more typically an irregular ferritic structure now known to be more familiar in directly transformed ultra-low carbon and low 

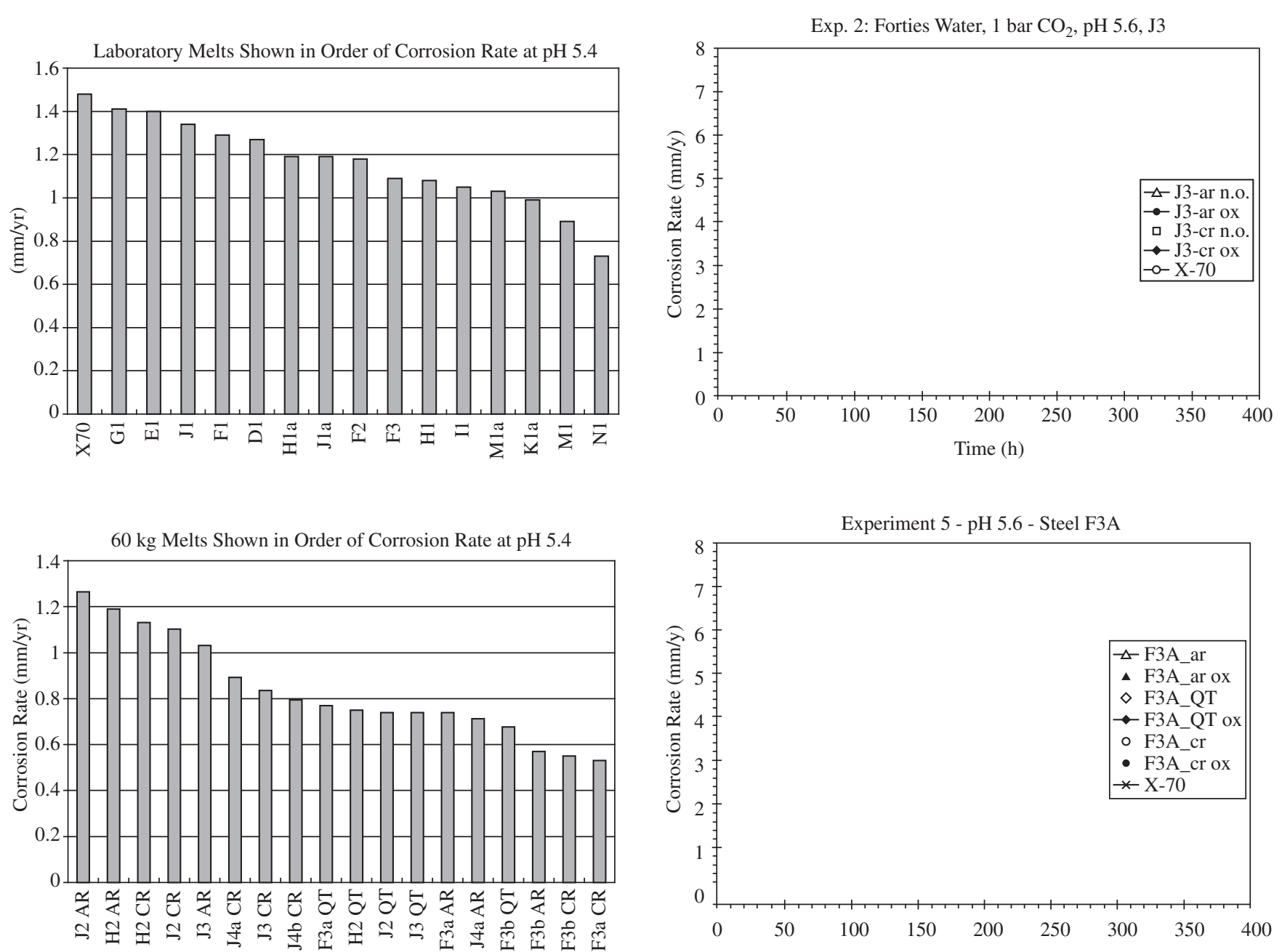

Figure 4. Laboratory sorting corrosion tests showing corrosion rate for a range of steels from the $25 \mathrm{~g}$ laboratory melts and $60 \mathrm{~kg}$ melts, illustrating the effect of alloying coupled with the processing route $(\mathrm{AR}=$ As-rolled; $\mathrm{CR}=$ Controlled-rolled; $\mathrm{QT}=$ Quenched and tempered $)$.

$60 \mathrm{~kg}$ Melts Shown in Order of Average Corrosion Rate at pH 5.6 (IFE Flow-Loop Tests 2 and 5)

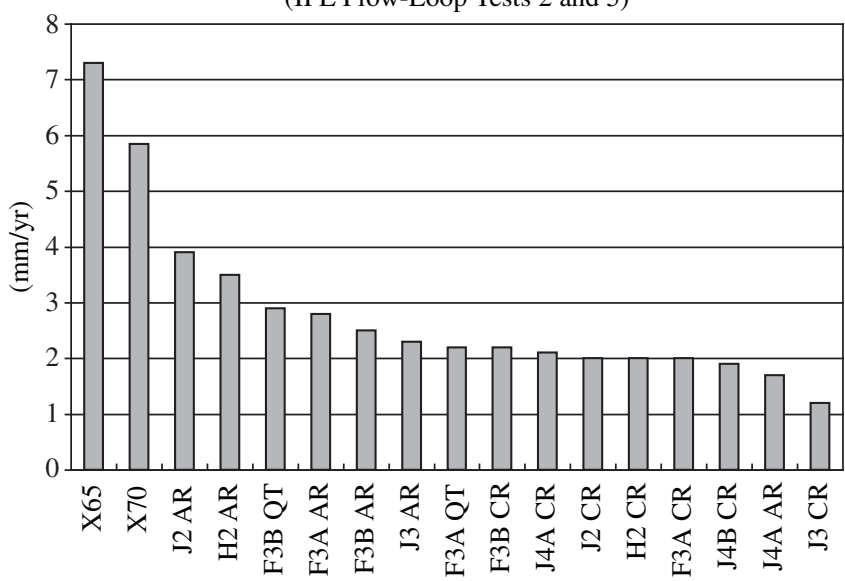

Figure 5. Flow-loop corrosion tests showing corrosion rate for a range of steels from the $60 \mathrm{~kg}$ melts.

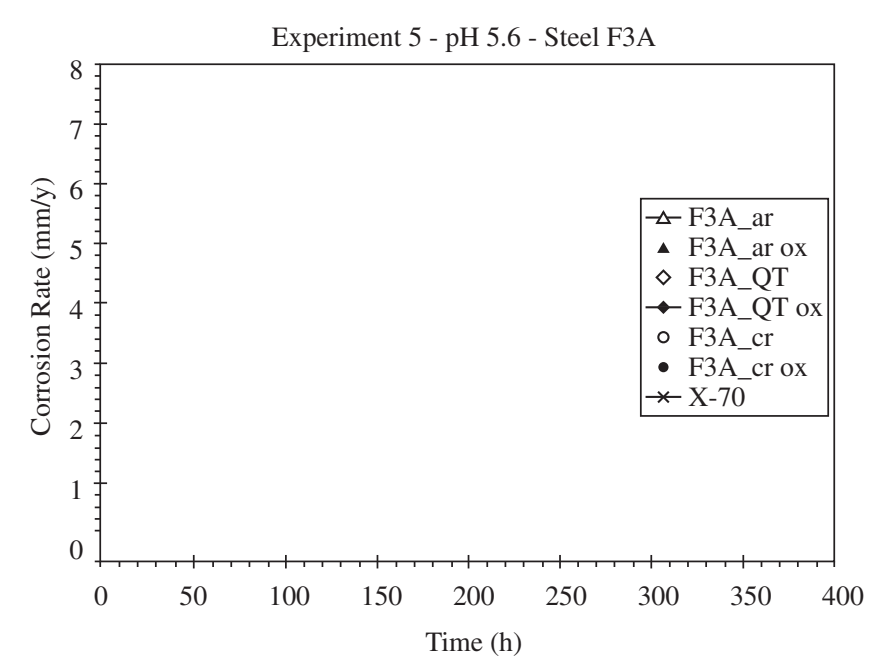

Figure 6. Flow-loop corrosion tests showing corrosion rate as a function of time.
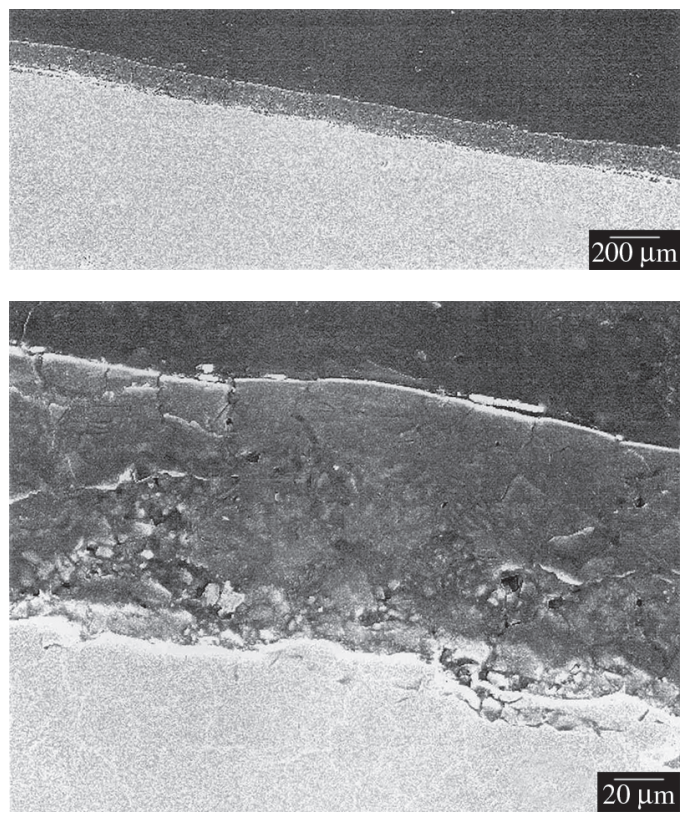

Figure 7. Scanning electron micrograph of the cross-section of the corrosion film formed on steel J4a during flow-loop testing. 


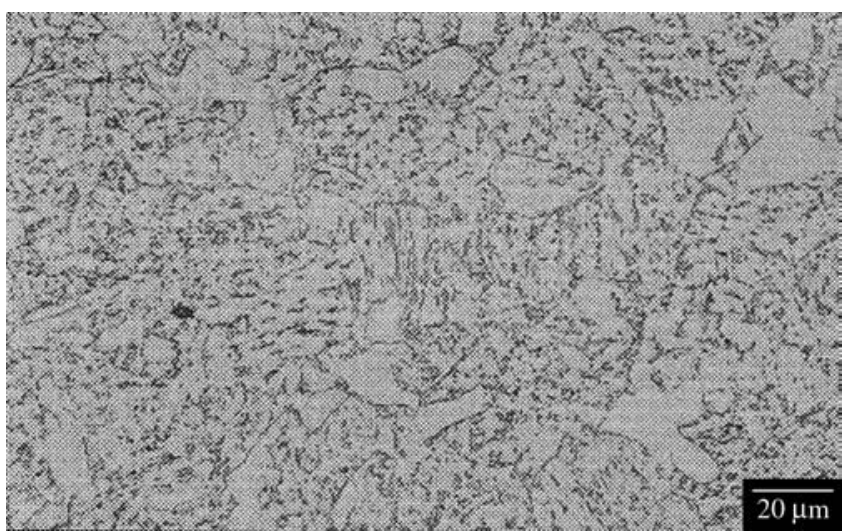

\section{a) Steel J2, As-rolled}

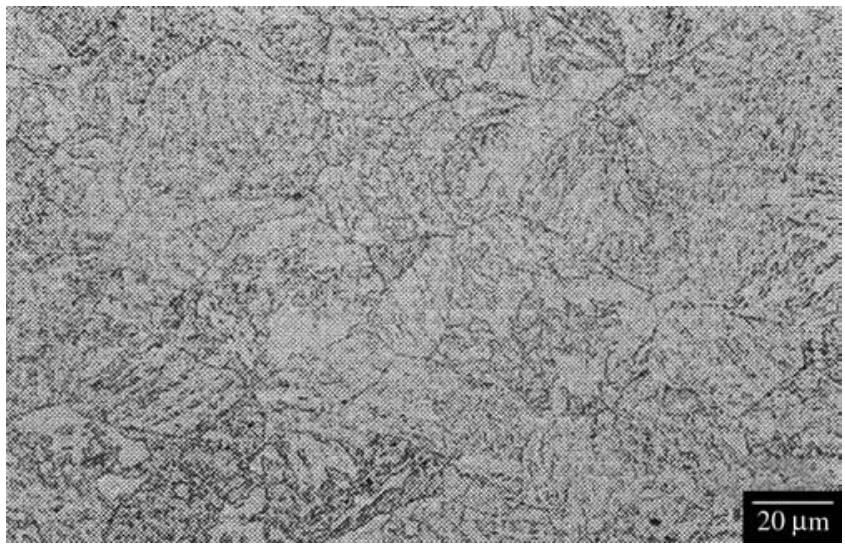

c) Steel J3, As-rolled

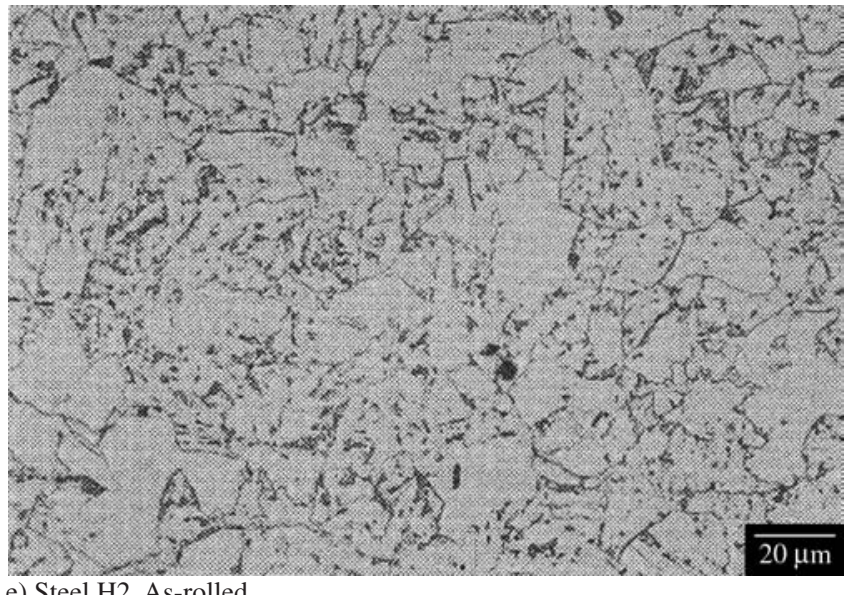

e) Steel H2, As-rolled

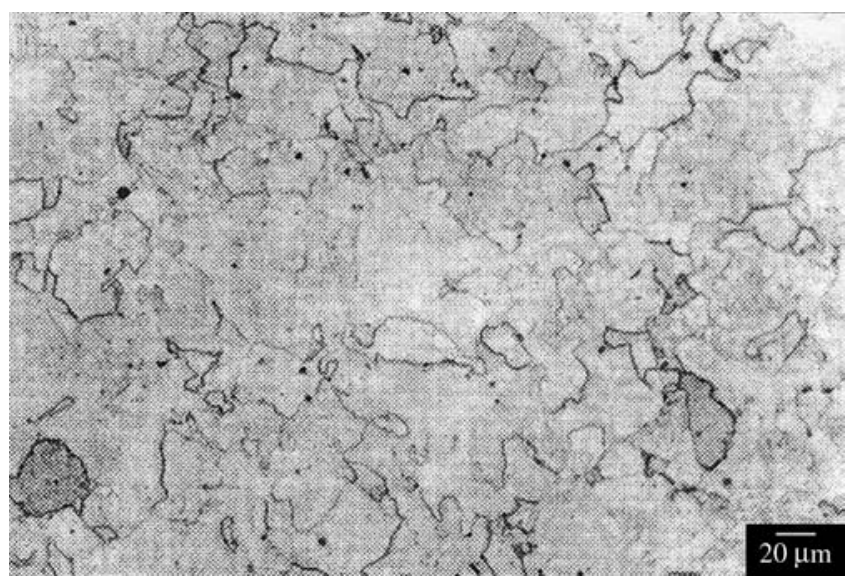

g) Steel F3a, As-rolled

$20 \mu \mathrm{m}$

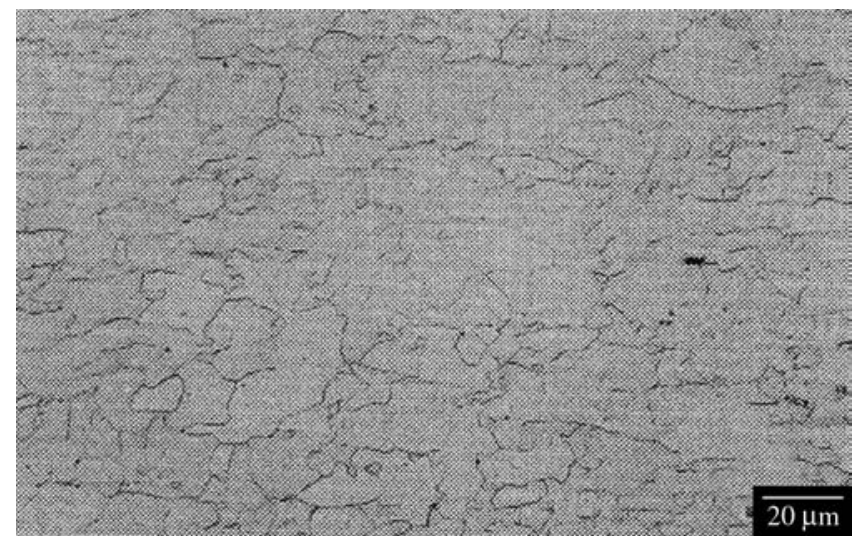

b) Steel J2, Control-rolled

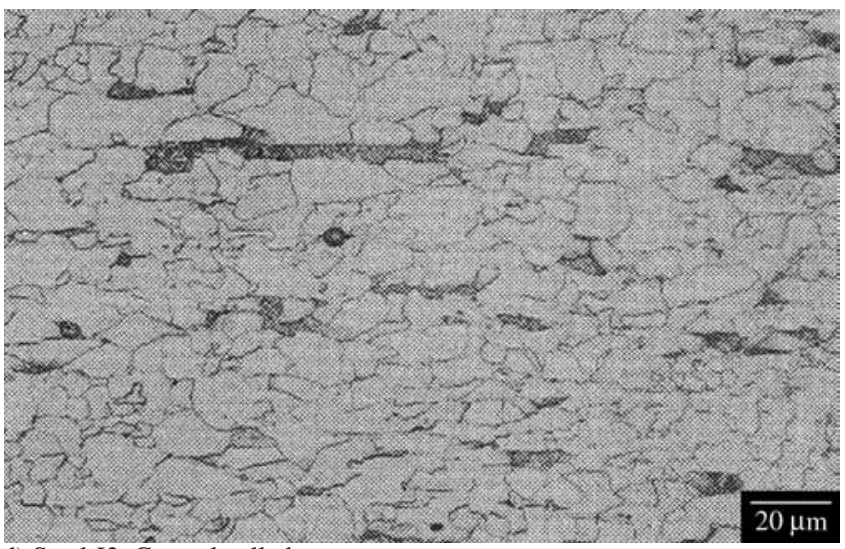

d) Steel J3, Control-rolled

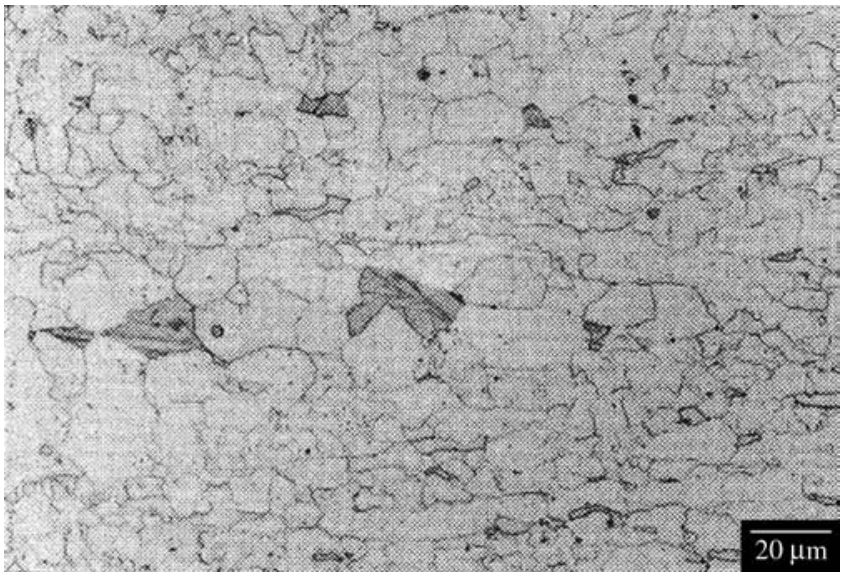

f) Steel H2, Control-rolled

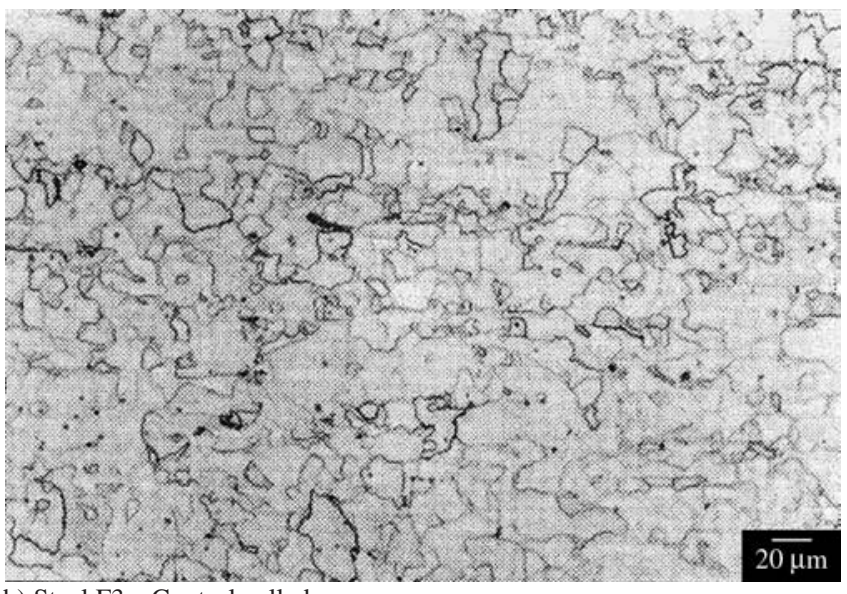

h) Steel F3a, Control-rolled

Figure 8. Light micrographs illustrating the microstructures of a selection of the experimental steels. To continued next page. 


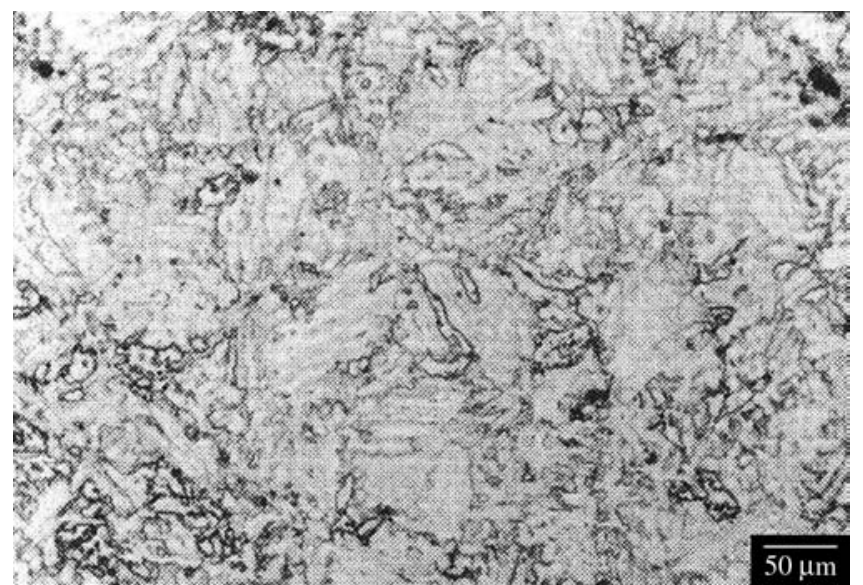

i) Steel J2, Quenched and tempered

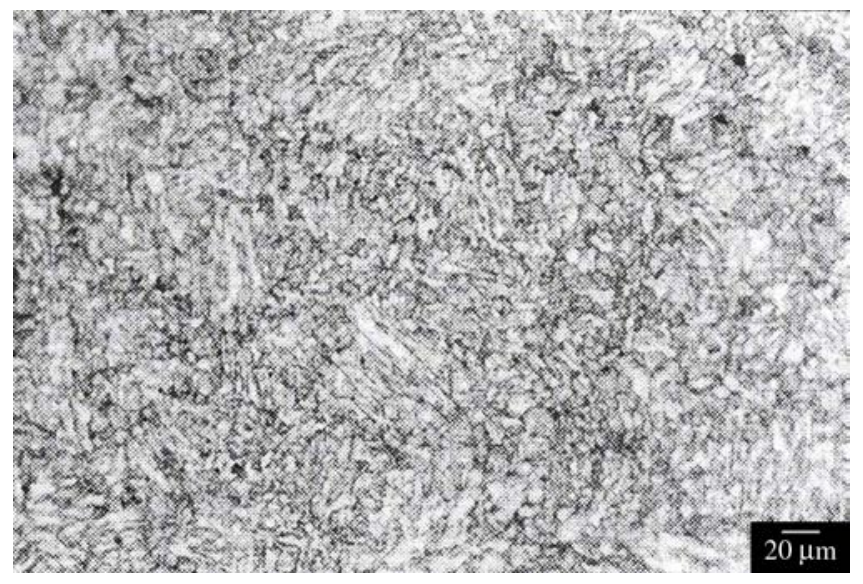

j) Steel J3, Quenched and tempered

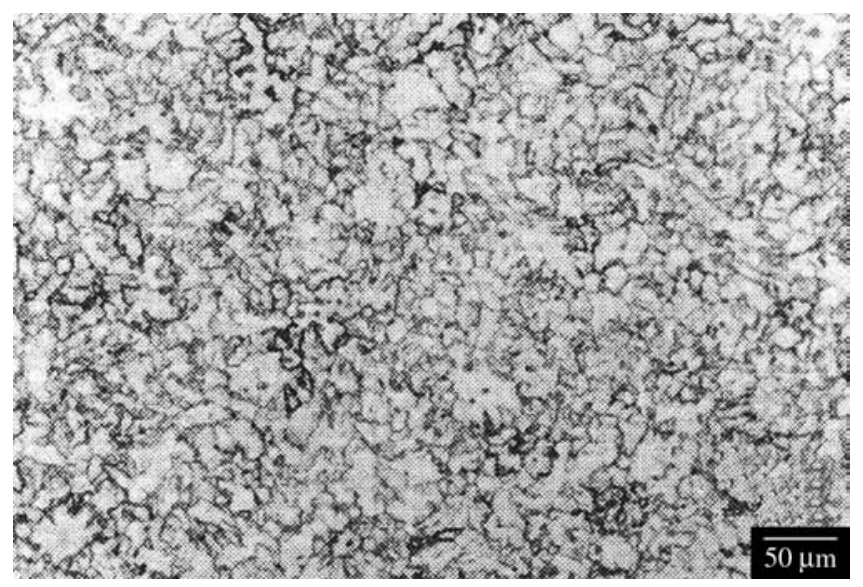

k) Steel H2, Quenched and tempered

Figure 8. Light micrographs illustrating the microstructures of a selection of the experimental steels.

carbon microalloyed steels ${ }^{21}$ : quasi-polygonal ferrite (for controlledrolled, CR) and quasi-polygonal ferrite plus granular bainitic ferrite (for as-rolled, AR). The QT samples exhibited a more customary tempered martensite microstructure.

The mechanical properties of the experimental steels are illustrated in Table 2 and Figure 9. Table 2 lists the hardness and tensile properties, and Figure 9 shows the Charpy impact energy values plotted against temperature, giving a clear indication of the relative ductile-brittle transition temperatures (DBTT). In general, the results
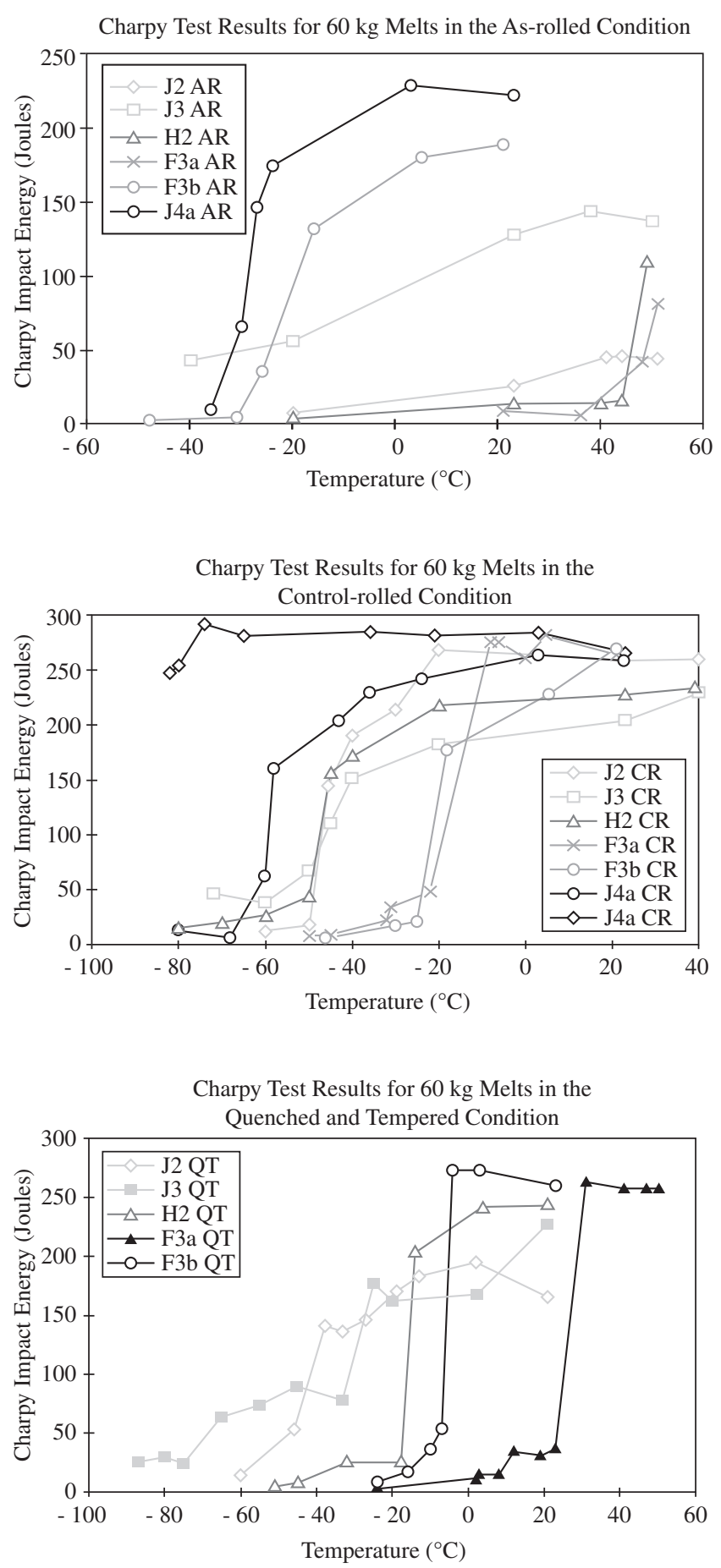

Figure 9. Charpy impact energy versus test temperature.

show that acceptable mechanical properties can be obtained. Poorer values could be related to oxide inclusions in the microstructure resulting from segregated regions in the cast ingot, or to the heat treatments used not giving the correct microstructures for certain of the experimental compositions. For example, the Ti-microalloyed steels, F3a and F3b, contained a large ferrite grain size distribution, with regions of coarse ferrite thought to result from incomplete austenitisation at the soaking temperature due to stabilisation of the ferrite by the alloying element additions. This is confirmed by the 
Table 2. Hardness and tensile properties of the $60 \mathrm{~kg}$ melts in the various processed conditions.

\begin{tabular}{|c|c|c|c|c|c|c|c|c|}
\hline Steel & U.T.S Nmm-2 & $0.2 \%$ P.S. & $0.5 \%$ P.S. & Upper Yield & Lower Yield & YS/UTS & Extension $(\%)$ & Hardness HV10 \\
\hline $\mathrm{J} 2 \mathrm{AR}$ & 844 & 656 & 702 & & & 0.83 & 12.6 & 268 \\
\hline $\mathrm{J} 2 \mathrm{CR}$ & 548 & & & 426 & 390 & 0.78 & 19.6 & 182 \\
\hline $\mathrm{J} 2 \mathrm{Q}+\mathrm{T}$ & 722 & 536 & 597 & & & 0.83 & 16.9 & 240 \\
\hline J3 AR & 934 & 711 & 792 & & & 0.85 & 8.9 & 330 \\
\hline J3 CR & 611 & 398 & 422 & & & 0.69 & 17.8 & 198 \\
\hline $\mathrm{J} 3 \mathrm{Q}+\mathrm{T}$ & 757 & 642 & 671 & & & 0.89 & 6.6 & 285 \\
\hline $\mathrm{H} 2 \mathrm{AR}$ & 722 & 553 & 597 & & & 0.83 & 14.1 & 242 \\
\hline H2 CR & 525 & & & 381 & 371 & 0.72 & 23.2 & 183 \\
\hline $\mathrm{H} 2 \mathrm{Q}+\mathrm{T}$ & 553 & 400 & 420 & & & 0.76 & 16.8 & 215 \\
\hline F3a AR & 588 & 450 & 473 & & & 0.80 & 14.4 & 190 \\
\hline F3a CR & 461 & 285 & 301 & & & 0.65 & 23.9 & 149 \\
\hline $\mathrm{F} 3 \mathrm{a} \mathrm{Q}+\mathrm{T}$ & 467 & 304 & 327 & & & 0.70 & 21.8 & 186 \\
\hline F3b AR & 487 & 311 & 327 & & & 0.67 & 19.7 & 163 \\
\hline F3b CR & 470 & 259 & 277 & & & 0.59 & 26.5 & 148 \\
\hline $\mathrm{F} 3 \mathrm{~b} \mathrm{Q}+\mathrm{T}$ & 447 & 244 & 260 & & & 0.58 & 28.7 & 145 \\
\hline $\mathrm{J} 4 \mathrm{a} A \mathrm{R}$ & 531 & 347 & 370 & & & 0.70 & 21.4 & 174 \\
\hline J4a CR & 497 & & & 347 & 347 & 0.70 & 24.2 & 168 \\
\hline $\mathrm{J} 4 \mathrm{~b}$ CR & 509 & 321 & 334 & & & 0.66 & $\mathrm{n} / \mathrm{a}$ & 188 \\
\hline
\end{tabular}

thermodynamic calculation of the equilibrium diagram, which in this case also predicted part of the Ti addition in the form of undissolved $\operatorname{Ti}(\mathrm{C}, \mathrm{N})$, meaning that the Ti is not fully participating in the expected way in this composition. Thermodynamic analysis also indicated that more pronounced segregation, as would be expected in continuously cast products, could result in delta-ferrite formation in the higher $\mathrm{Si}$ and $\mathrm{Cr}$ casts.

A typical result of the hot ductility tests, conducted to detect whether transverse cracking during continuous casting may be a problem with these new steel compositions, is shown in Figure 10 for steel J3. The reduction in hot ductility is not severe, with a minimum reduction in area of $56 \%$ recorded at $850{ }^{\circ} \mathrm{C}$, which should not present any problems for continuous casting.

In contrast, the bead-on-plate weldability tests on $\mathrm{J}$ and $\mathrm{H}$ series steels in the controlled-rolled condition (Table 3 ) showed that it would be difficult to meet heat affected zone hardness below the accepted minimum of 248 VPN common to fabrication welding specifications at these levels of alloying element addition. Whilst the bead-on-plate data suggest it may be difficult to deploy these compositions for linepipe steels that require fabrication by fusion welding, the heat affected zone hardness under fabrication conditions is more closely related to girth welding procedures than to alloying per se. However, as the hardness was borderline in many cases, it is felt that this is an issue that should be addressed further.

\section{Conclusions}

- Performance against targets: A corrosion rate 5 times lower than X70 and 6 times lower than X65 was achieved, surpassing the initial target requirement set. This was achieved at a price factor of 1.58 times the cost of X70, only marginally above the initial target cost of 1.5. Adequate mechanical properties were achieved but the steels exhibiting the best corrosion resistance required alloying element levels that caused them to fall short of the weldability criteria required of linepipe steels;

- $\mathrm{Cr}$ addition was the most effective in reducing corrosion rate, provided that sufficient $\mathrm{Cr}$ is left in solid solution;

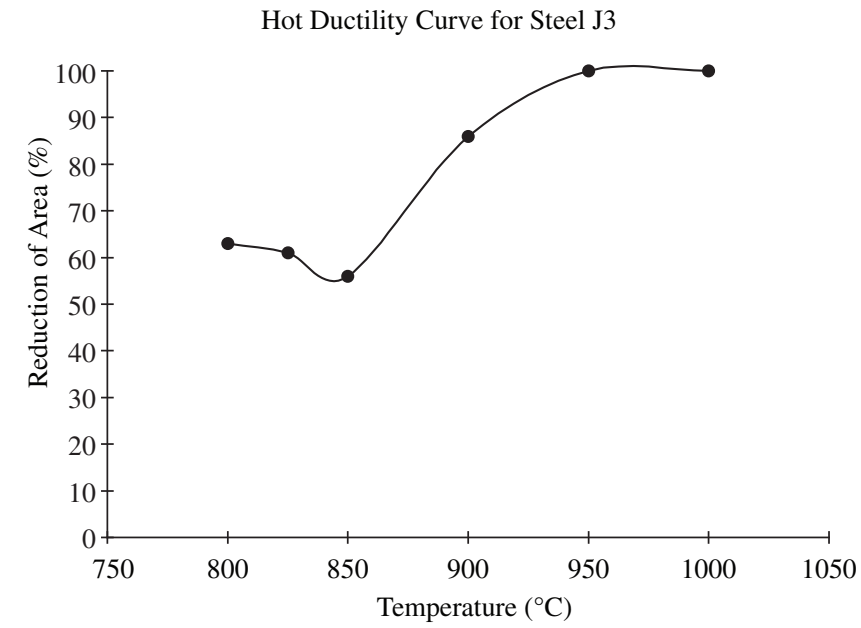

Figure 10. An example of the hot ductility test results.

Table 3. Maximum hardness values recorded from the bead-on-plate weldability test specimens.

\begin{tabular}{cccc}
\hline & \multicolumn{3}{c}{ Hardness VPN } \\
Steel & Parent & HAZ & Weld metal \\
\hline J2 CR & 179 & 283 & 327 \\
J3 CR & 185 & 351 & 351 \\
H2 CR & 179 & 242 & 281 \\
J4b CR & 169 & 285 & 279 \\
\hline
\end{tabular}

- 3 wt. (\%) Cr addition offered the target reduction in corrosion rate; 1.5 wt. (\%) $\mathrm{Cr}$ was insufficient to ensure this level of resistance;

- Amongst the customary microalloying additions, $\mathrm{V}$ was beneficial to corrosion rate; Ti may also be beneficial; 
- Enhanced $\mathrm{Si}$, and additions of $\mathrm{Mo}$ and $\mathrm{Cu}$, were beneficial to corrosion rate;

- Corrosion rates from 3 to 10 (steel composition J4b) times less than the reference steel were recorded;

- The best corrosion rates (of selected steels in flow-loop tests) were recorded for steels in the controlled-rolled condition rather than as-rolled;

- The effect of the pre-oxidation experiments was inconclusive and needs further work - it is probable that it does not accurately reflect mill-scale;

- The most promising steel compositions (in terms of both corrosion resistance and mechanical properties) were in the $\mathrm{J}$ series e.g. J3 based upon 3 wt. (\%) $\mathrm{Cr}$ at $0.07 \mathrm{C}-0.53 \mathrm{Mn}+$ enhanced $\mathrm{Si}(0.6)+\mathrm{V}$ microalloying $(0.36)+\mathrm{Mo}(0.31)+\mathrm{Cu}(0.26)$. ( $\mathrm{Ti}$ addition can be beneficial to corrosion but the mechanical properties were more variable and difficult to control);

- The corrosion rate is improved by formation of a Cr-rich film: this film forms under conditions when iron carbonate films are barely stable and grows down to $\mathrm{pH} 5$. V addition improves the adherence of this film;

- The mechanical properties achievable were found to be: PS 400 - 700 MPa; UTS 600 - 900 MPa; El\% 9 - 20; Charpy impact energies up to $>250 \mathrm{~J}$ with DBTT down to $<-80^{\circ} \mathrm{C}$. (However, some problems were identified with the cleanliness of the casts and the formation of incorrect microstructures for the heat treatments used, which means that there is some scope to improve the mechanical properties above those measured for some of the experimental steels);

- Hot ductilities are sufficient (in the steels assessed) to avoid transverse cracking problems during continuous casting; and

- Weldability remains an issue for the best composition ranges identified, limiting their suitability at the present time to downhole applications.

\section{Acknowledgments}

The programme was sponsored by Agip, BP, Elf, Statoil, Corus Group, Dalmine (Tenaris Group) and Vallourec. The project work was largely conducted and managed by Dr M Dougan with assistance from Dr RM Grau; the flow loop tests were carried out at IFE, Norway under the direction of Dr A Dugstad and M Seiersten, and the hot ductility tests at City University, London, by Professor B Mintz. The following members of the Steering Group are also gratefully acknowledged for their advice: A Kopliku (Agip), MB Kermani (BP), J-L Crolet (Elf), S Olsen (Statoil), AW Johnson (Corus Group), G Cumino, S Renato (Dalmine), C Linne (Vallourec) and especially the late Professor J Nutting, Emeritus Professor at the University of Leeds.

\section{References}

1. UK-Brazil Integrity \& Corrosion Control Network. http://www.uk-brazilcorrosion.net.
2. Crolet J-L. 10 th European Corrosion Congress. Barcelona, Spain. 1993. p. 473.

3. Cross DE. 'Corrosion 93'. NACE Annual Conference. Houston. 1993. p. 118.

4. Crolet J-L. In 'Predicting $\mathrm{CO}_{2}$ Corrosion in the Oil and Gas Industry'. Kermani M.B. and Smith L.M., editors. EFC (European Federation of Corrosion); 1994.

5. Kermani MB, Smith LM. 'CO Corrosion Control in Oil and Gas Production-Design Considerations'. EFC (European Federation of Corrosion); London: IoM; 1999.

6. Rabald V. 'Corrosion Guide'. Elsevier; 1968.

7. ASM Metals Handbook. 'Corrosion'. vol. 13, 1987.

8. Dugstad A. 'Mechanism of protective film formation during $\mathrm{CO}_{2}$ corrosion of carbon steels'. 'Corrosion 98'. NACE Annual Conference. San Diego. 1998. p. 31

9. Dugstad A, Hemmer H, Seiersten M. 'Effect of steel microstructure upon corrosion rate and protective iron carbonate film formation'. 'Corrosion OO'. NACE Annual Conference. Orlando; 2000.

10. Alhajiji JN, Reda MR. Corrosion Science. 1993; 34:1899.

11. Ikeda I, Ueda M. 'CO Behaviour of Cr-Containing Steels', EFC (European Federation of Corrosion); London: IoM. 1994. p. 13.

12. Nice PI, Ueda M. 'The effect of microstructure and chromium alloying content to the corrosion resistance of low-alloy steel well tubing in seawater injection service'. 'Corrosion 98'. NACE Annual Conference. San Diego. 1998. p. 3.

13. Nyborg R, Dugstad A, Dronen P. 'Effect of chromium on mesa corrosion attack of carbon steels', 'Corrosion 00'. NACE Annual Conference. Orlando. 2000

14. Nice PI, Takeda H, Ueda M. 'The development and implementation of a new alloyed steel for oil and gas production wells'. 'Corrosion 00'. NACE Annual Conference. Orlando. 2000. p. 154.

15. Ueda M. and Takebe $\mathrm{H}$. 'Corrosion resistance of low $\mathrm{Cr}$ bearing steel in sour and sweet environments'. 'Corrosion 02'. NACE Annual Conference. Denver. 2002. p. 41.

16. Kermani MB, Gonzales JC, Linne C, Dougan M, Cochrane RC. 'Development of low carbon Cr-Mo steels with exceptional corrosion resistance for oilfield applications'. 'Corrosion 01'. NACE Annual Conference. 2001. p. 1065.

17. Kermani MB, Gonzales JC, Turconi GL, Edmonds DV, Dicken G, Scoppio L. 'Development of superior corrosion resistance $3 \% \mathrm{Cr}$ steels for downhole applications'. 'Corrosion 03'. NACE Annual Conference. San Diego. 2003. p. 3116.

18. Mintz B. City University, London, UK, private communication.

19. Davies RH, Dinsdale AT, Chat TG, Barry TI, Rand MH. High Temp. Sci.; 1990; $26: 251$.

20. Ansara I, Sundman B. in 'Computer Handling and Dissemination of Data’. Report CODATA. 1987. p. 154

21. Rehman A, Edmonds DV. 'Ferrite Morphologies in Ultra-Low Carbon Manganese Steels', 'HSLA Steels 2000'. Xi' an. Guoquan L, Fuming W, Zubin W. and Hongtao Z. editors. Beijing: The Metallurgical Industry Press. 2000. p. 241. 